\title{
Positive Accounting Theory and Agency Costs: A Critical Perspective
}

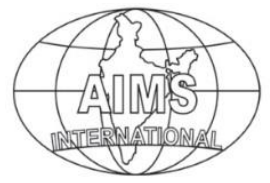

DOI: $10.26573 / 2020.14 .2 .3$

Volume 14, Number 2

May 2020, pp. 101-113

\author{
Jagriti Srivastava \\ Pankaj Kumar Baag \\ Indian Institute of Management \\ (jagritis12fpm@iimk.ac.in) \\ (baagpankaj@iimk.ac.in)
}

We study the relevance of Positive Accounting Theory (PAT) in today's dynamic environment. It focuses on firms' choice of accounting techniques. It also considers the manner in which firms will react to proposed accounting records. Even after its huge contribution to the field of accounting, it is not fully developed. In this view, the agency theory breaks down as a positive theory as it does not cater for the theory of accounting regulatory development. We need to develop affluent theories based on either better rationality assumption or which considers a broader view of organisational behaviour

Keywords: Positive Accounting Theory, Accounting Standards, Agency Theory, Rationality

\section{Introduction}

International Financial Reporting Standards (IFRS) set regular rules with the goal that financial reports can be steady, straightforward and practically identical around the globe. They indicate how organizations must keep up and report their records, characterizing kinds of exchanges and different occasions with monetary effect. IFRS was built up to make a typical accounting language, with the goal that organizations and their budget summaries can be predictable and solid from organization to organization and nation to nation. In India, notwithstanding fulfilling statutory revelation prerequisites under the Companies Acts fiscal summaries should likewise agree to accounting guidelines all together for those financial statements to give a true and fair view. Accounting guidelines contain codes regarding how certain matters ought to be managed in an organization's financial statements. Ind AS represents Indian Accounting Standard. It provides joined models for IFRS. Ind AS are records and arrangements that give standards to acknowledgement, estimation, treatment, introduction and divulgences of accounting transactions in the Ind AS financial reports. Securities and Exchange Board of India (SEBI) is an administrative body of the Government of India. It controls the securities market. SEBI is basically set up to ensure the interests of investors in the capital market. It advances the improvement of the protections advertise and directs the business. The target of SEBI is to guarantee that the Indian capital market works in a precise way and give investors a straightforward situation for their investment. Essentially, the essential explanation behind setting up SEBI was to avert acts of malpractices in the capital market of India and advance the improvement of the capital markets. 


\section{Positive Accounting Theory}

Positive accounting emerged with the accounting studies that generated in late 1960s. This concept was organised as a school of thought by Ross Watts and Jerold Zimmerman. Positive Accounting Theory attempts to make great forecasts of genuine occasions and make an interpretation of them to accounting transactions. While normative theories will, in general, suggest what ought to be done, Positive Theories attempt to clarify and foresee activities, for example, which accounting transactions firms will pick how firms will respond to recently proposed accounting standards. Its general aim is to comprehend and foresee the decision of accounting policies crosswise over varying firms. It perceives that financial outcomes exist. Under this theory, three hypotheses have been brought into light:

1. Keeping all other things constant, managers of firms with reward plans are bound to pick accounting procedures that shift reported income from future periods to the present time frame.

2. Keeping all other things constant, the bigger a company's debt/equity ratio, the more probable the company's manager is to choose accounting procedure that shifts reported earnings from future periods to the present time frame.

3. Keeping all other things constant, the larger the firm, the almost certain the manager is to pick accounting procedures that defer reported earnings from current to future periods.

In relation to this, politicians have the power to impact upon organizations earnings re-distributions by method for corporate taxes, guidelines, allowances and so on. Besides, certain groups of voters have motivating forces to allow for the "nationalization, confiscation, separation or rules of an industry or enterprise", which thus are believed to give incentives to politicians to propose such activities (Stigler, 1971).

Under PAT, firms need to amplify their prospects for survival, so they compose themselves effectively. Firms are seen as the aggregation of the agreements they have gone into. In connection to PAT, on the grounds that there should be proficiency, the firm will need to minimize expenses related to contracts. In case of an unregulated economy, the promoters and original shareholders have incentives to contract to supply the audited financial statements. These agreements were included in articles of association and in the contracts between the organisation and creditors (Watts, 1977). It leads to decreasing agency costs.

Continuing with the above discussion, agency costs exists because of the conflict of interests between shareholders and managers, shareholders and bondholders. The managers have the incentives of transferring wealth to themselves at the cost of shareholders and bondholders (Watts \& Zimmerman, 1979).Bondholders and investors anticipate the managers' conduct and appropriately discount the cost of the bonds or shares at the time of issue. Consequently, the managers of another corporation get less for the shares and bonds he sells than he would have if he could guarantee that he would keep on going about as he did when he possessed the firm (i.e., when there were no outside investors or bondholders).

So, in an unregulated economy, accounting procedures are constructed in such a way to diminish the agency costs of contracts. But as it varies across firms, the accounting procedures also varies across firms giving rise to diversity. There is a demand for expectations of the impacts of accounting procedures on both the managers' and auditors' welfare by means of disclosure to claims. The auditor contracts 
with the investors (and creditors) to screen the executives, and he is lawfully amenable in the event that he neglects to report breaks of covenants in the company's articles or by-laws.

For this purpose, accounting theories are build. Accounting texts (and theories) which detail how managers look to manipulate profits and the ensuing impacts of those manipulations on investors and bondholders not just improve the managers' capacity to monitor such actions, yet in addition give the auditor readymade contentions to use against such methods in consultation with management(Watts \& Zimmerman, 1979). In a regulated economy, private citizens, civil servants, and legislators have motivations to utilize the forces of the state to improve themselves off and to mix for that reason. Financial accounting statements play out a focal job in these riches moves and are influenced both directly and by implication by the political procedure. Government commissions frequently utilize the substance of financial statements in the administrative procedure (rate setting, antitrust, and so forth.).

This, thusly, gives the board motivations to choose accounting procedures which either decreases the costs they bear or increases the advantages they get because of the activities of government controllers and officials. Since public utilities have motivating forces to propose accounting procedures for rate-making purposes which boosts the market value of the firm, their contentions are helped if accounting standard-setting bodies order similar accounting procedures for financial reporting. The guidelines and regulations which result from government supervision of business increase the professional and educational demands requests for accounting theories. The justification demand for theories additionally extends with regulation.

In continuation with the above discussion, proponents and adversaries of extraordinary intrigue legislation (or aspirants before administrative and regulatory councils) must give contentions for the positions they advocate. In the event that these positions incorporate changes in accounting procedures, accounting theories which fill in as rationale (i.e., justifications) are valuable (L.H., 1972). The controllers (politicians and administrators) are judicious. Nonetheless, they perceive that theory validation has expenses and advantages. The legitimacy of an accounting theory won't be resolved if the expense to evaluate the legitimacy of a hypothesis is more prominent than the advantages. Since the interest is for theories which have an open intrigue direction, when such a basis has been given, the advantages to controllers related with distinguishing a coherent the false notion in accounting theory might be very little. Actually, regardless of whether the theory is known to have a legitimate error, there might be motivations not to perceive the ambiguity. That is, the theories may at present have an incentive as a reason notwithstanding its sensible status. Market failure theories are vital for politicians to legitimize an accounting regulatory procedure over a private market for accounting data. The politicians may not be "fooled" by "theory illusion" and might be uninterested in or reluctant (due to disincentives) to perceive coherent ambiguities (Watts, R. L., \& Zimmerman, J. L., 1986).

In the economics context, a market failure is said to happen when either the amount or nature of a good delivered in an unregulated market contrasts based on what is indicated to be the social optimum. The social ideal is characterized as that product which boosts total social welfare and is achieved just if the costs of sources of inputs and outputs are equivalent to their social marginal costs. In private markets, makers and buyers seek after their individual interests. In this manner, it is asserted, the output 
of private markets varies from the social ideal at whatever point social expenses and advantages vary from private expenses and advantages (Leftwich, 1980).

So, Positive accounting theory will be helpful only in the case that it can give rich expectations of certain significant phenomenon. We would contend that notwithstanding a few works in the zone positive accounting theory has not helpfully anticipated accounting regulatory development (Benston, 1969). This theory is to a great extent worried about three joint indicators of lobbying behaviour also, accounting method choice dependent on suspicions of self-interested managers' wealth maximization. Managers of firms making large benefits and conceivably mishandling monopoly powers, it is guessed, are probably going to utilize a heap of accounting strategy decisions to decrease reported income. Their very own reference to social responsibility disclosure and its relationship to their fundamental contentions is dark. None of the examinations utilizes each of the three of the (joint) hypothesis of behaviour. Most, in fact, just utilize the size or political cost hypothesis, and therefore alone they should be thought about the shaky test of the original argument. Second, none of the tests takes the chance to look at the management practices other than the picked disclosure variable that one may hope to exist if self-interested income diminishing methodologies were being received as theorized, in this way further weakening the tests (Milne, 2002).

Now, consider the three hypothesis of behaviour. The intellectual predecessor of positive accounting theory is the income smoothing hypothesis (Becker, G. M, DeGroot, M. H, 1964). According to this hypothesis, income smoothing is viewed as a function of rational behaviour of humans with a few assumptions: - a) the managers of the organisation are utility maximizers b) the main reasons for market risk are variation in the income and uncertainty of earnings c) the main stimulus of share value is the dividend payout ratio d) firms' share value is the main determinant of managers' utility (Beidleman, 1973; Watts, R. L., \& Zimmerman, J. L., 1986). It essentially assumes that the market is inefficient i.e. the market reacts on the basis of reported accounting numbers without taking into consideration the transparency of procedures to generate these numbers. However, it is not required for the stock market prices formation to consider functional fixation in order to create smoothing incentives. It is ample for the managers to believe that the market considers accounting numbers. A study conducted shows that 83 percent of Fortune 500 controllers disagree with the idea of market efficiency (Mayer - Sommer, 1979). Managers, nonetheless, may distort their beliefs and predictions to the standard setters, if they have incentives in doing so. With the help of an approach to control this, it was found that managers do not consider market efficiency (O’Keefe, T. B., \& Soloman, S. Y, 1985). In most of the cases, other things remaining constant, the higher the uncertainty in firms, higher the incentive for the managers for smoothing earnings (Vivien Biette, Stephen Brown, David Ewers, Brian John, Stewert Manson, Dylan Thomas, Michael Turner, 1994).

On the other hand, positive accounting theory is based on the concept of market efficiency. So, the market captures observable smoothening incentives. There are three overlying accounting approaches: - a) the opportunistic behaviour b) efficient contracting and information perspectives (Holthausen \& Verrecchia, 1990). According to opportunistic behaviour, the managers are wealth maximisers and try to maximise their own wealth which is directly proportional to their performance, the risk arising for the managers in case of company failure. So, the managers have the option to go with choices which maximises the firms' cash flows and hence value of 
the firm so that they get maximum amount of incentives. When accounting choices do not have a direct effect, then also managers' incentives arise. So, other things remaining constant, managers will choose income reducing accounting methods if the political costs are high, and they will choose income increasing accounting methods if the agency costs of debt and equity are high. Most of the empirical studies are done on the basis of opportunistic behaviour hypothesis.

The second one in efficient contracting. According to efficient contracting, all the contracts that decrease agency costs strengthen earnings management. Nonetheless, all the contracts are considered to be efficient because they result in an increase in firm value. Empirically, it is difficult to differentiate between efficient contracting and opportunistic behaviour hypothesis.

Last concept i.e. information perspective has been emerged as a recent concept. It considers income smoothing as an earnings management strategy. As there is always information asymmetry between managers and claimholders, it explains how the existence of discretion to smooth earnings can act in the best interest of shareholders (Dye R.A., 1988). For instance, it can enhance the perception of firms' potential shareholders regarding the firm value or by declining their perception regarding the bankruptcy risk (Trueman \& Titman, 1988). The accounting methods chosen shows the expectations of managers regarding the future cash flows. Some studies have also suggested that separation of ownership and control increases the chances of smoothing behaviour. Although owners control outside, they have direct access to information. So, they do not rely on published information. The managers of firms with dispersed ownership will be involved more in the smoothening process in order to decrease information asymmetries. They will also be more involved in order to reduce the systematic employment risk and enhance the value of the firm.

The existence of incentive schemes with high and low limits create a conflict between managers and shareholders. So, by smoothing the income, it helps the managers in transferring the wealth from shareholders to themselves (Kamin, 1975). So, it empirically proved that smoothening of income is directly proportional to management controlled firms (Amihud \& Mendelson, 1983; Kamin, 1975). Despite that, some firms have not been able to correctly identify the relevance of accounting structure (Hunt III, H. G., \& Hogler, R. L., 1990).

In the examination of positive theory of accounting, authors inspect the job of "marginalism" in theory of accounting. Likewise, with the help of order of laws, the philosophy related to free-economy agreements turned up focal in the area of accounting at a recent date because of the push to isolate "fact" from "reality" also "positive" to "normative" theory. Truly, the idea of significant worth in accounting is borrowed one of two from a labour based or a utility-based origin. The last mentioned, as indicated by the authors, decides the general estimation of the products and works in a providence "by their relative commitment to the utility of buyers. In the labourbased theory, interestingly, the selective source of significant worth is gainful labour". Following "value theory" to its current manifestation in marginalism. It was inferred that there exists two primary characteristics of the theory that replicate in thought of accounting (Tinker et al., 1982).

They pointed out difference in early aspect and subsequent changes in accounting. The early [aspect] is the accentuation on individualism (regardless of even if the sole proprietor or the enterprise to be a lawful "individual") that has offered to seize inquiries concerning the class incorporations of" people" and the roles played by 
accountants in class clashes. The subsequent accentuation in the field of accounting has always been an endeavour to protect objectivity and freedom by avoiding "abstract" inquiries of significant worth and restricting bookkeeping information to "objective" market prices (factual \& present).'

That last accentuation, where the accountant is exhibited as an "impartial, harmless historian," starts in the profession's desire "to reject the obligation that accountants bear for molding subjective expectations which, thus, influence choices about capital allotment and the disbursement of earnings between and inside social classes. All the more in a general sense, the nation for equality has both philosophical and mechanical ramifications. Standard research in accounting "is commanded by a faith in visible authenticity - the case that there is a universe of target realism that continues freely of people and which will have a certain nature or substance which is understandable (Chua, 2005). From that presumption, it pursues that people might be portrayed in a target way free of social setting. The proper model of learning for standard scholars is hence the "hypothetic-deductive" or "logical" model, with its accentuation on allinclusive innovative associations.

\section{Positive Accounting Theory and Agency Costs}

Agency theory is one of the examples of failure of positive accounting theory. It originates from its dependence on a presumption of level headed conduct which in one regard is narrow and in another regard is both wide and conflicting. Agency relationship can be defined as an agreement under which at least one people (the principal(s)) connect with someone else (the agent) to play out some administration for their benefit which includes appointing some basic leadership position to the agent. In the event that the two gatherings to the relationship are utility maximizers, there is valid justification to accept that the agent won't generally act to the greatest advantage of the principal. Competition in the product and factor markets will in general drive costs towards smaller than the average expense in an action. Managers should subsequently persuade their organisations to build effectiveness to upgrade the chances of survival. Be that as it may, product and factor market disciplinary powers are frequently more fragile in new activities and activities that include generous economic rents or semi rents. In these cases, observing by the company's inside control framework and the market for corporate control are increasingly significant (Jensen \& Posner, 1996). The principal can limit divergences from his interest by establishing appropriate incentives for the agent and by incurring monitoring costs designed to limit the aberrant activities of the agent (Jensen \& Meckling, 1976).

As the association between the investors and the managers of an organization is perfect to the meaning of a pure agency relationship, it should not come as a disturbance to find that the issues related with the "separation of ownership and control" in the modern diffuse ownership enterprise is personally connected with the general agency problem. The issue of actuating an "agent" to act as though he were boosting the "principal's" welfare is very broad. It exists in all associations and in every agreeable exertion - at each degree of the board in firms, in colleges, in mutual companies, in cooperatives, in government organisations and authorities, in associations, and in relationships classified as agency relationship, for example, those normal in the performing art and the market for real estate.

However, the amount of agency costs depends, among different things, on statutory and customary law and human creativity in contriving contracts. Borrower bankruptcy 
is conversely identified with the agency costs of undertaking physical investments. Both the law and the advancement of agreements important to the competition are the results of a past process in which there were strong incentives for people to limit agency costs. In addition, there were elective organisational structures accessible, and chances to develop new ones. Agency costs additionally encroach on publicly held firms, most likely limiting their capacity to issue outside equity. For instance, equity issuance may weaken managerial incentives (by bringing down the debt-equity proportion) or send a bad signal to outside investors (Bernanke \& Gertler, 1986). The development of theories to clarify the structure which agency costs take in each one of these circumstances (where the authoritative relations contrast altogether), and how and why they are conceived will prompt rich theory of organisations which are currently lacking in economics and social science(Jensen \& Meckling, 1976). The choices of managers will include not just the advantages he gets from monetary returns yet, in addition, the utility produced by different non-monetary parts of his pioneering exercises, for example, the physical arrangements of the workplace, the engaging quality of the workplace staff, the degree of representative control, the sort and the measure of altruistic commitments, individual relations ("fellowship," "regard, etc) with representatives, a bigger than the ideal PC to play with, or purchase of production inputs from companions. The ideal mix (without charges) of the different financial and non-financial advantages are accomplished when the minor utility got from an extra dollar of use (estimated net of any gainful impacts) is equivalent for each nonmonetary thing and equivalent to the negligible utility got from an extra dollar of aftercharge acquiring influence (riches).

The power of "agency theory" as a clarification of accounting and authoritative development is an ongoing, exceptionally persuasive association of the standard suspicion. No place are the similitudes among the orders of accounting and law more apparent than in the theory of market at determines much significant legitimate idea and the office based ideas so inescapable in significant standard accounting research. All such closeness are particularly critical in two of them- jobs that create contracts and market play in accounting research based on agency, and furthermore concerning the neoclassical monetary economic fundamental to this area of examination and theory improvement (Hunt III, H. G., \& Hogler, R. L., 1990).

Agency connections will include relevant agency costs if it is expected (as it generally seems to be) that both the parties i.e. agent and the principal seek for the maximisation of their utility and the operator will subsequently not every time operate to the greatest advantage of the head. Indeed, it is commonly inconceivable for both the principal or agent at zero expense to guarantee that the agent would settle on ideal choices from the principal's perspective. In most office connections the principal and the agent will cause positive observing and holding costs (non-monetary just as financial), and what's more there will be some dissimilarity between the agent's choices and those choices which would augment the welfare of the principal. What could be compared to the decrease in welfare experienced by the principal because of this dissimilarity is additionally an expense of the office relationship, and we allude to this last cost as the "residual loss" (Jensen \& Meckling, 1976).

At the point when connected to an authoritative setting, for example, a company, agency theory expels the thought that an association is an important element. Rather, most associations are just lawful fictions which fill in as a nexus for a lot of contracting connections among people The private enterprise or firm is basically one type of 
legitimate fiction which fills in as a nexus for contracting connections. Seen thusly, it looks bad to attempt to recognize those things that are "inside" the firm from those things that are "outside" of it. There is undeniably just a large number of complex connections (for example contracts) between the lawful fiction (the firm) and the proprietors of work, material and capital information sources and the consumers of output. (Jensen \& Meckling, 1976).

Seen as such, the firm turns out to be minimal in excess of equilibrium of contending contractual connections went into by people, some of whom may represent different associations. The agency and property rights writing has been an affluent wellspring of testable significance for researchers from a few orders, particularly accounting. The acknowledgment that probably the most evident agency connections in the corporate environment (for example the manager/investor relation and the agent/debt holder connection send) use contracts dependent on accounting numbers has driven accounting analysts to utilize agency theory in endeavours to clarify, in addition to other things, the interest for financial reports, uncertainties in accounting strategy decision, campaigning attempts before administrative firms, and stock market responses to compulsory changes in accounting. In light of agency theory, positive scholars see accounting reporting as a feature of the organisation's contract procedure. Positive scholars don't see assorted variety in financial practices as tricky, yet as a need altogether for "contracting parties to tailor their accounting strategies to their very own particular conditions."

Norm setters ought not to view cross-sectional varieties in accounting methods as a sign of administrations' endeavours to control accounting numbers so as to deceive investors (and apparently others). In addition, "Norm-setters ought to consider the impacts of prospective accounting measures on current contracts (so as to maintain a strategic distance from) unexpected wealth moves between parties of the firm (Watts, R. L., \& Zimmerman, J. L., 1986). While the agency writing has delivered useful bits of knowledge for accounting analysts, its wide-spread acknowledgement by standard researchers has gotten basic consideration in a few recent investigations related to the profound accountants. Rising up out of these basic investigations is the acknowledgement that accountants have been immensely impacted by neoclassical financial aspects, that underestimated suppositions are precarious to a full comprehension of the socio-political condition of accounting, and that the two of these issues add up fundamentally to belief system in current accounting thought (Hunt III, H. G., \& Hogler, R. L., 1990).

\section{Positive Accounting Theory, Agency Costs and Accounting Regulatory Development}

Agency theory is limited in its meaning of judicious conduct with regard to its supposition that people want to augment utility and that utility is spoken to by riches. Rather than its narrow presumption about inclinations, it is broad with respect to the distribution of the power. Moreover, it contains conflicting suppositions about the sorts of activities over which power exists. It is difficult to accept the idea of market failure theories were ignored from a positive point of view. While such oversight is conceivable, it positively isn't plausible. Therefore, doubtlessly it considers ideological inclination to go into what is marketed as intellectual enquiry. The interdisciplinary nature of accounting research gives numerous chances to 
standardizing investigation into the requirement for as well as the ideal idea of accounting regulations. Contending normative theories can be as advantageous to the public as contending descriptive theories (Ruland, 1984). The irregularity has taken into consideration the particular use of contentions, for example, the market for excuses contentions. It is our assumption that no single theory will totally clarify accounting regulatory development.

Rather, we expect the juncture of theories which are equipped for foreseeing probably a few parts of accounting regulatory development will be most useful for regulating normative decisions. The estimation of utilizing different theories to illustrate social phenomena has been perceived by researchers in other sociologies, including economics furthermore, social anthropology (DiMaggio, 1986). So, the theories which focus on the rational behaviour of individuals and groups would be able to predict accounting regulatory development more accurately. The advantage of such theories is to a great extent attached to how explicitly they can demonstrate the idea of inclinations and the appropriation of intensity in the public arena. There are numerous methodologies which may be taken to demonstrate better inclinations and power. Ethical cognition research finds that there are phases of ethical advancement in people extending from the "preconventional" stages where people obey rules and regulations so they won't get rebuffed to the "post-conventional" stage where people pick and pursue ethical standards.

Persistent with the recognized performance, management advancement in accounting may result not from a desire with respect to people to boost wealth. Rather, people might be inspired by moral standards which make accounting guideline alluring (Conroy, 2010). The "economic theory of regulation" centres around the sound conduct of people in a more extensive setting than the manager shareholder relationship. Under this theory, people and society are seen as being in competition among themselves for the intensity of government to accomplish wealth transfer by means of the economic guideline. That is, economic guideline is viewed as an item and the allotment of the item is dictated by free-market activity. The key element of the economic theory of guideline is that it requires an examination of all groups influenced by the entry of the revelation demonstrations. The theory holds that guideline speaks to the result of various contending parties arriving at an equilibrium. By concentrating exclusively on investors, past studies may have been excessively confined. For this situation, barring other influenced parties might be viewed as an "omitted variables" issue. The presence of compulsory exposure might be clarified by an increasingly complete examination which contains other influenced parties (Posner, 1974). This economic theory of regulation is consistent with May and Sundem's model of accounting policy decision. It shows that accounting policy decisions are decided using an aggregate decision rule.

Also, the model especially demonstrates that there are numerous and contending parties which impact accounting policy decisions (May R.G., 1976). A model may be meant for looking at financial information disclosure. The model sets that the utilization of power is impacted by the accompanying elements: (a) the relationship among groups; (b) heterogeneous objectives among groups; (c) heterogeneous convictions about innovation among groups, and (d) shortage of assets. At the point when these conditions are met, contention will emerge (Pfeffer, 1981). One consequence of contention among various groups is that party gathering won't have comparative rankings concerning what is to be unveiled for the increasingly complete 
discourse of the issues prompting differential rankings for information disclosure. A specific group evaluating the impacts of disclosure may verify that it is useful, inconvenient or impartial concerning its interests (Jensen T.S., 1985). The basic component in the goals of the contention is the arrangement of people or on the other hand groups with adequate power to drive a decision. By recognizing the sources of power, it is conceivable to foresee what decisions will be made.

\subsection{Institutional Theories}

Institutional theories have been created in human science to show and clarify hierarchical advancement and change. These theories keep up that institutional improvement is driven by more intricate conduct than self-interest maximisation boosts with respect to people. Two instances of such theories which may help portray the improvement of accounting guideline are organisational legitimacy and the generation of trust.

\subsection{Organisational Legitimacy}

Organizational legitimacy is characterized as existing when there is a "compatibility between the social qualities related to or suggested by hierarchical exercises and standards of worthy conduct in the bigger social framework of which the associations are a part "(Dowling J., 1975). Fundamental organizational legitimacy is a procedure, legitimation, by which an association looks for endorsement (or evasion of assent) from gatherings in the society. Legitimation might be important to guarantee an association's continuation. It is to the procedure of legitimation that traits the advancement of corporate social disclosure. Theory of accounting regulatory development dependent on organizational legitimacy is obviously conceivable. Business associations, for example, companies could look for exposure guideline with an end goal to show social duty and maintain a strategic distance from cultural approvals which may even incorporate expulsion.

Legislators could pass revelation guideline to legitimize themselves as defenders of the public interest when voters are disappointed with corporate conduct. At the point when the quality of their work has been addressed, accounts.

Might look for guidelines to keep up their status as a profession. It is imperative to take note of that cultural desires would not need to be unitary all together for legitimizing action to occur. A few people may not mind one way or the other about corporate execution or corporate disclosure. Be that as it may if a powerful group of individual requests or would be conciliated by an action like disclosure guideline, organisations may look for authenticity with that group notwithstanding when the group is a minority in the society. Organisations may have nothing to lose except for something to pick up by legitimizing exercises under such conditions (Kaplan S.E., 1991).

\subsection{Production of Trust}

Trust is made out of basic understandings (foundation desires) and "guidelines characterizing the unique circumstance or background" of the exchange (constitutive expectations) (Zucker, 1987). Trust is disrupted when either constitutive or foundation desires are damaged. At the point when conventional methods of trust are disturbed, a third mode, institutional based trust creates. Institutional-based trust development 
increased during the 1800 s and 1900 s due to the interruption of conventional methods of trust. The disturbances are established in expanded social heterogeneity brought about by migration and immigration, and a new economic association identified with the insecurity of firms and organizations (Neu, 1991). Production of trust indicates the potential for clarifying institutional advancement through accounting guideline. Institutional trust advancement is relied upon to slack disturbance of trust (similarly as accounting theories which are reasons are relied upon to slack changes in accounting practice). The idea shows guarantee to give more extravagant a theory of guideline than can be given by rationale economics alone (Kaplan S.E., 1991).

\section{Conclusion}

In order to increase the role of research in making correct predictions, both descriptive and normative theories should be created. Positive accounting theory to date has made little commitment to a portrayal of accounting regulatory development and along these lines isn't helpful alone for standardizing decision making. The reason behind this is the assumption of rationality. In real life, this assumption is a bit difficult to observe. With the dynamic environment, new theories also need to be developed. The absence of reality and divergence appears to reflect the description of the theory as a reason to advance the researchers theory. With the blend of both positive theory of accounting and new theories developed, better prediction can be made in this dynamic world. It suggests future implication for research also. Considering the changes and complexities in environment, new theories for a better prediction can be developed.

\section{References}

1. Amihud, Y., \& Mendelson, H. (1983). Price Smoothing and Inventory. The Review of Economic Studies, 50(1), 87. https://doi.org/10.2307/2296956

2. Becker, G. M, DeGroot, M. H. (1964). Measuring utility by a single-response sequential method. Behavioral Science, 226-232.

3. Beidleman, C. R. (1973). Income Smoothing: The Role of Management. 16.

4. Benston, G. J. (1969). The value of the SEC's accounting disclosure requirements. The Accounting Review.

5. Bernanke, B., \& Gertler, M. (1986). Agency Costs, Collateral, and Business Fluctuations (No. w2015; p. w2015). National Bureau of Economic Research. https://doi.org/10.3386/w2015

6. Chua, W. F. (2005). Radical Developments in Accounting Thought. In Accounting, the Social and the Political (pp. 55-66). Elsevier. https://doi.org/10.1016/B978-008044725-4/50009-6

7. Conroy, E. (2010). Ethical attitudes of accounting practitioners: Are rank and ethical attitudes related? Journal of Business Ethics, 183-194.

8. DiMaggio, P. (1986). Structural analysis of organizational fields: A block model approach. Research in Organisational Behaviour.

9. Dowling J., P. J. (1975). Organizational legitimacy: Social values and organizational behavior. Pacific Sociological Review, 122-136.

10. 10. Dye R.A. (1988). Earnings management in an overlapping generations model. Journal of Accounting Research, 195-235.

11. Holthausen, R. W., \& Verrecchia, R. E. (1990). The Effect of Informedness and Consensus on Price and Volume Behavior. 19. 
12. Hunt III, H. G., \&Hogler, R. L. (1990). Corporate ownership and accounting choice: A critical analysis. Critical Perspectives on Accounting, 53-67.

13. Jensen, M. C., \&Meckling, W. H. (1976). Theory of the Firm: Managerial Behavior, Agency Costs and Ownership Structure. 78.

14. Jensen, M. C., \& Posner, R. A. (1996). Agency costs of free cash flow, corporate finance, and takeovers. In J. S. Bhandari \& L. A. Weiss (Eds.), Corporate bankruptcy (pp. 11-16). Cambridge University Press. https://doi.org/10.1017/CBO9780511609435.005.

15. Jensen T.S., S. D. F. (1985). Selective association in conditioned stress-induced analgesia: Functional differences in interoceptive and exteroceptive sensory pathways. Behavioral and Neural Biology, 218-221.

16. Kamin, J. H. (1975). Optimal Portfolio Revision with a Proportional Transaction Cost. Management $\quad$ Science, 21(11), 1263-1271. https://doi.org/10.1287/mnsc.21.11.1263

17. 17. Kaplan S.E., R. R. G. (1991). Positive theory, rationality and accounting regulation. Critical Perspectives on Accounting, 361-374.

18. Leftwich, R. (1980). Market failure fallacies and accounting information. Journal of Accounting and Economics, 2(3), 193-211. https://doi.org/10.1016/01654101(80)90002-6

19. L.H., R. (1972). SEC accounting practice and procedure. John Wiley \& Sons, Volume 1.

20. May R.G., S. G. L. (1976). Research for accounting policy: An overview. The Accounting Review, 747-763.

21. 21. Mayer-Sommer, A. P. (1979). Understanding and Acceptance of the Efficient Markets Hypothesis and Its Accounting Implications. 20.

22. Milne, M. J. (2002). Positive accounting theory, political costs and social disclosure analyses: A critical look. Critical Perspectives on Accounting, 369395.

23. Neu, D. (1991). Trust, impression management and the public accounting profession. Critical Perspectives on Accounting, 295-313.

24. O'Keefe, T. B., \& Soloman, S. Y. (1985). Do managers believe the efficient market hypothesis? Additional evidence. Accounting and Business Research, 6779.

25. Pfeffer, J. (1981). Power in organizations. Marshfield, MA: Pitman, Vol 33.

26. Posner, R. A. (1974). Theories of economic regulation.

27. Ruland, R. G. (1984). Duty, obligation, and responsibility in accounting policy making. Journal of Accounting and Public Policy, 223-237.

28. Stigler, G. J. (1971). The theory of economic regulation. The Bell Journal of Economics, 3-21.

29. Tinker, A. M., Merino, B. D., \& Neimark, M. D. (1982). The normative origins of positive theories: Ideology and accounting thought. Accounting, Organizations and Society, 7(2), 167-200. https://doi.org/10.1016/0361-3682(82)90019-8

30. Trueman, B., \& Titman, S. (1988). An Explanation for Accounting Income Smoothing. Journal of Accounting Research, 26, 127. https://doi.org/10.2307/2491184

31. Vivien Biette, Stephen Brown, David Ewers, Brian John, Stewert Manson, Dylan Thomas, Michael Turner. (1994). Extraordinary items and income smoothing: A Positive Accounting Approach. Journal of Business Finance and Accounting. 
32. Watts, R. L. (1977). Corporate Financial Statements, a Product of the Market and Political Processes. Australian Journal of Management, 2(1), 53-75. https://doi.org/10.1177/031289627700200104

33. Watts, R. L., \& Zimmerman, J. L. (1986). Positive accounting theory.

34. Watts, R. L., \& Zimmerman, J. L. (1979). The Demand for and Supply of Accounting Theories: The Market for Excuses. 34.

35. Zucker, L. G. (1987). Institutional theories of organization. Research in Organisational Behaviour, 443-464.

\section{About Our Authors}

Jagriti Srivastava is a doctoral student at Indian Institute of Management, Kozhikode, India in Finance, Accounting and Control area. She has completed her Master in Commerce from Banaras Hindu University in 2018. Her research interest lies broadly in corporate finance, corporate governance and earnings management.

Pankaj Kumar Baag is an assistant professor at Indian Institute of Management, Kozhikode, India in Finance, Accounting and Control area. He has done FPM (PhD) from Indian Institute of Management, Calcutta. His research interest lies broadly in credit risk in banks, loan covenants, financial inclusion, corporate governance in banks and oil \& gas accounting. 